Military Technical College

Kobry El-Kobbah,

Cairo, Egypt

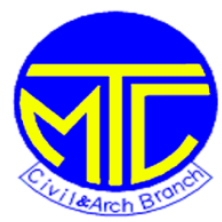

$12^{\text {th }}$ International Conference on Civil and Architecture Engineering

ICCAE-12-2018

\title{
Repairing Reinforced Concrete Beams with Openings by Ferrocement Laminates
}

\author{
Prof. Yousry B I Shaheen ${ }^{1}$ Dr. Noha M Soliman² Eng. Fathya El-Araby \\ ${ }^{1}$ Professor, Dept. of Civil Eng. Menoufia Univ. ${ }^{2}$ Assoc.Prof. Dept. of Civil Eng. Menoufia Univ, ${ }^{3}$ Research Student, Egypt.
}

\begin{abstract}
This paper presents a proposed method for repairing reinforced concrete beams with openings using ferrocement laminates as a viable alternative to steel plates which are directly glued to the cracked tension face of the beam by epoxy resins. The results of experimental investigation to examine the effectiveness of this method are reported and discussed including strength, deflections, tensile and compressive strains, cracking, ductility ratio and energy absorption properties of the repaired reinforced concrete beams. Twelve reinforced concrete beams with and without openings were cast and tested until complete failure. All test specimen having the dimensions of $100 \mathrm{~mm}$ width, $200 \mathrm{~mm}$ depth and $2000 \mathrm{~mm}$ long and tested under four lines loadings with effective span $1900 \mathrm{~mm}$. The main variables were type of steel mesh welded and expanded metal mesh, number of layers of steel mesh, volume fraction of repaired materials. The experimental results showed that high ultimate and serviceability loads, better crack resistance control, high ductility, and good energy absorption properties could be achieved by using the proposed techniques.
\end{abstract}

Keywords: Ferro-cement; Beams with openings; Experimental; program; Deformation characteristics; Cracking; Ductility ratio; Energy absorption properties.

\section{INTRODUCTION}

Ferrocement is a structural material primarily composed of cement mortar reinforced with layers of small diameter wire mesh. It has been defined by ACI as "A type of reinforced concrete commonly constructed of hydraulic cement mortar reinforced with closely spaced layers of relatively small wire diameter mesh. The mesh may be made of metallic or other suitable materials. The fineness of the mortar matrix and its composition should be compatible with the opening and tightness of the reinforcing system it is meant to encapsulate. The matrix may contain discontinuous fibers." Many investigators have reported the physical and mechanical properties of this material and numerous test data are available to define its performance for construction and repair of structural elements (Fahmy and Shaheen et. Al 1994,(2) 1999.(3) and 2004,(4). The structural concept of ferrocement has been shown to posses excellent mechanical properties in terms of crack control, impact resistance, and toughness which are achieved by close spacing and uniform dispersion of reinforcement within the matrix. These unique qualities of structural performance can be taken advantage of in design and construction for a variety of applications, provided precautions are taken to ensure uniform and adequate cover for the steel and dense impermeable matrix is used (5). These will provide sufficient protection 
from corrosion for the steel, whilst at the same time forming a water-tight structural element that will prevent steel exposure through abrasion and erosion. Irons (6) introduced laminated ferrocement as a new production technique of ferrocement. This technique has been used successfully for a wide variety of structural repairs and has proven to impact and corrosion resistant. Water tanks and swimming pools could be renovated using an unbounded ferrocement laminate on the interior surface while pressure vessels and tanks were reinforced by an interior and exterior laminate containing high tensile wires between mesh layers. Anwar et. Al (7) presented a rehabilitation technique for reinforced concrete structural beam elements using ferrocement. This technique involved strengthening of reinforced concrete beams by the application of hexagonal chicken wire mesh and skeletal steel combined with ordinary plastering. Another study on using ferrocement as a structural repair material was presented by Fahmy, Shaheen, and El-Dessouky (8). They used ferrocement laminates to strengthen and repair cracked circular reinforced concrete tanks. A sandwich type composite construction was formed by using the laminates on both the outer and inner faces of the defected tanks. Another .study on using ferrocement as a structural repair material was presented by Paramasivanm, Ong, and Lim (9). They investigated the flexural behavior of reinforced concrete beams repaired with epoxy resin injection and strengthened using thin ferrocement laminates attached to the tension face of the damaged beams. E.H.Fahmy, Y.B.Shaheen, and Y.S.Korany, repairing reinforced concrete beams by ferrocement, (10). They reached that repairing concrete beams with a U- shaped layer around the beam cross -section increased the gain in the ultimate moment about three times that obtained when only one laminate attached to the tension face was used . Also, the $U$-shaped layer resulted in about double the increase in the energy absorption obtained using one layer, yet it gave relatively lower increase in the ductility ratio. This paper presents the experimental results on the use of laminated ferrocement for strengthening and repairing of damaged reinforced concrete beams with openings previously damaged until failure. The results showed that repaired beams achieved higher ultimate loads which were more than their respective ultimate loads with better deformation characteristics, high ductility and energy absorption properties.

\section{Experimental Work}

The experimental program comprised casting and testing of twelve reinforced concrete beams having the dimensions of 200x100x2000mm1900 mm. Table 1 shows details of test specimens while Fig. 1 shows reinforcement configurations of all test spemens.

\section{Table 1: Details of Test Specimens.}


Proceedings of the $12^{\text {th }}$ ICCAE-12 Conference, 3-5 April, 2018

MQ 2

\begin{tabular}{|c|c|c|c|c|c|c|c|}
\hline \multirow[b]{2}{*}{$\begin{array}{c}\text { Beam } \\
\text { number }\end{array}$} & \multirow[b]{2}{*}{$\begin{array}{c}\text { Number } \\
\text { of } \\
\text { openings }\end{array}$} & \multicolumn{3}{|c|}{ Steel Mesh } & \multicolumn{3}{|c|}{ Reinforcing Steel Bars } \\
\hline & & Type & $\begin{array}{l}\text { No. of } \\
\text { Layers }\end{array}$ & $\begin{array}{c}\text { Volum } \\
\text { e } \\
\text { Fractio } \\
\text { n, \% }\end{array}$ & Tens. & Comp. & Stirrups \\
\hline B1 & - & Welded & 2 & 2.769 & $2 \phi 12$ & $2 \phi 10$ & $6 \phi 6 / \mathrm{m}$ \\
\hline B2 & - & expanded & 1 & 2.992 & $2 \phi 12$ & $2 \phi 10$ & $6 \phi 6 / \mathrm{m}$ \\
\hline B3 & 1center & expanded & 1 & 3.03 & $2 \phi 12$ & $2 \phi 10$ & $6 \phi 6 / \mathrm{m}$ \\
\hline B4 & 3 & expanded & 1 & 3.049 & $2 \phi 12$ & $2 \phi 10$ & $6 \phi 6 / \mathrm{m}$ \\
\hline B5 & 3 & welded & 2 & 2.83 & $2 \phi 12$ & $2 \phi 10$ & $6 \phi 6 / \mathrm{m}$ \\
\hline B6 & 3 & welded & 3 & 2.957 & $2 \phi 12$ & $2 \phi 10$ & $6 \phi 6 / \mathrm{m}$ \\
\hline B7 & 3 & expanded & 2 & 3.585 & $2 \phi 12$ & $2 \phi 10$ & $6 \phi 6 / \mathrm{m}$ \\
\hline B8 & 2 & expanded & 1 & 3.069 & $2 \phi 12$ & $2 \phi 10$ & $6 \phi 6 / \mathrm{m}$ \\
\hline B9 & 2 & welded & 2 & 2.81 & $2 \phi 12$ & $2 \phi 10$ & $6 \phi 6 / \mathrm{m}$ \\
\hline B10 & 1right & expanded & 1 & 3.03 & $2 \phi 12$ & $2 \phi 10$ & $6 \phi 6 / \mathrm{m}$ \\
\hline B11 & 1right & welded & 2 & 2.79 & $2 \phi 12$ & $2 \phi 10$ & $6 \phi 6 / \mathrm{m}$ \\
\hline B12 & 1center & welded & 2 & 2.79 & $2 \phi 12$ & $2 \phi 10$ & $6 \phi 6 / \mathrm{m}$ \\
\hline
\end{tabular}



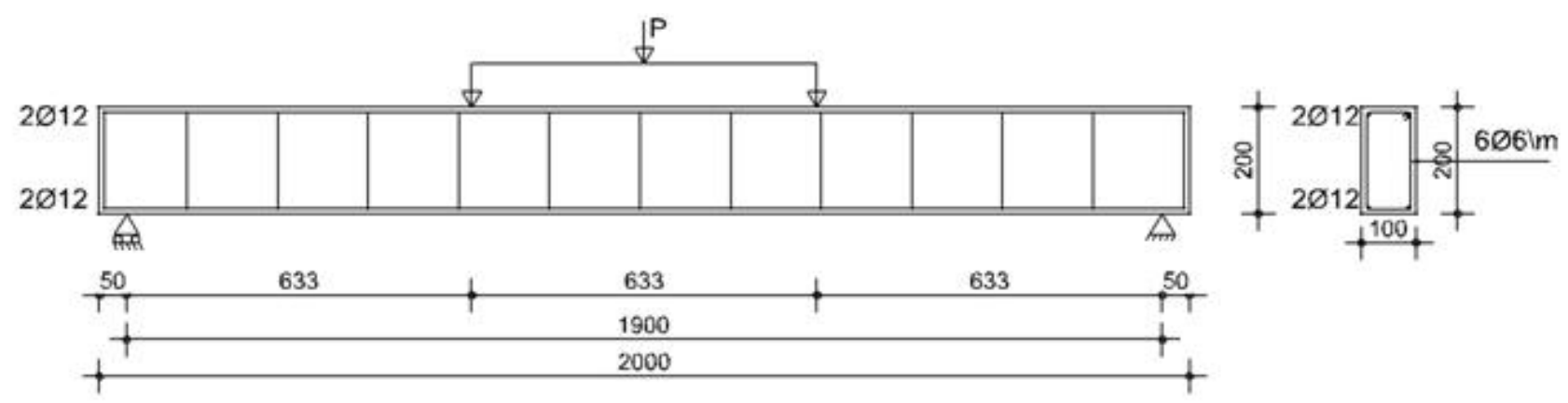

(7)
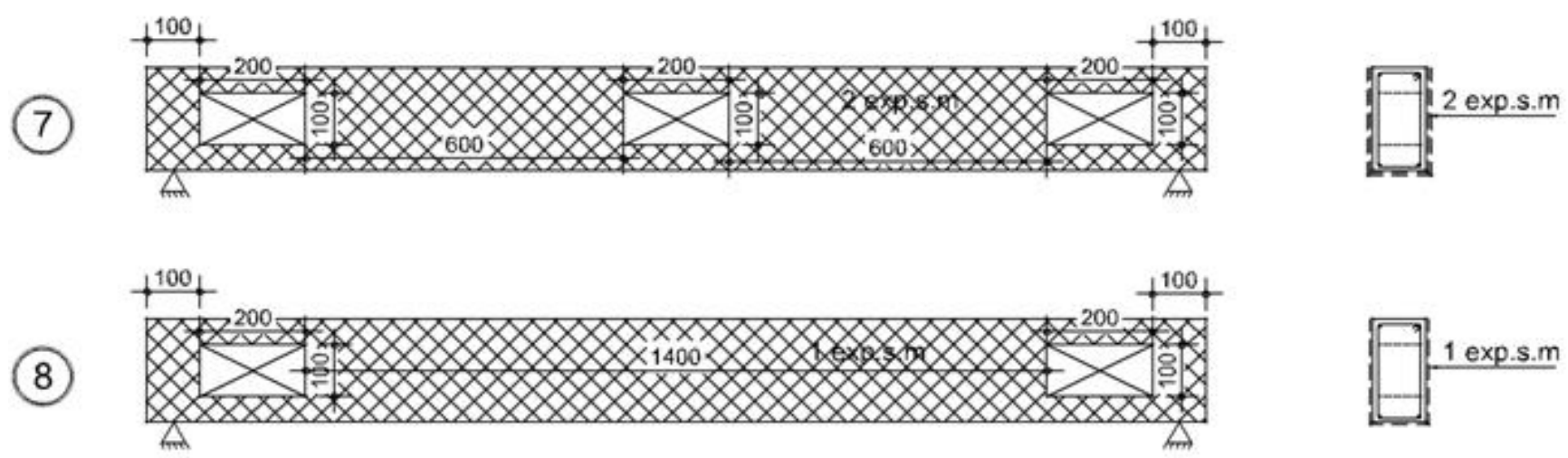

(9)
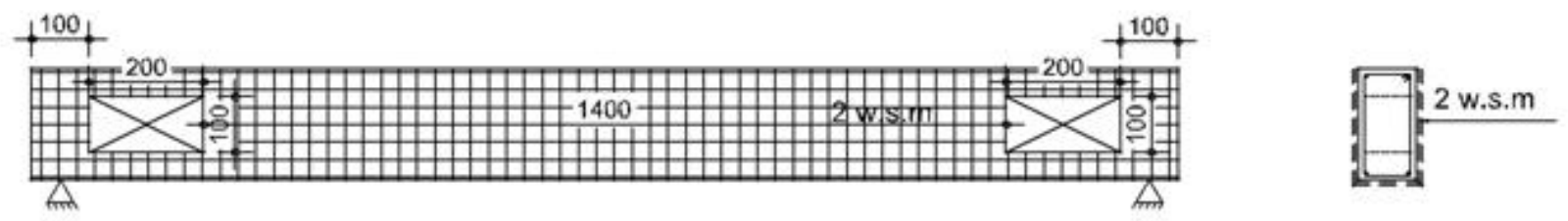

(10)
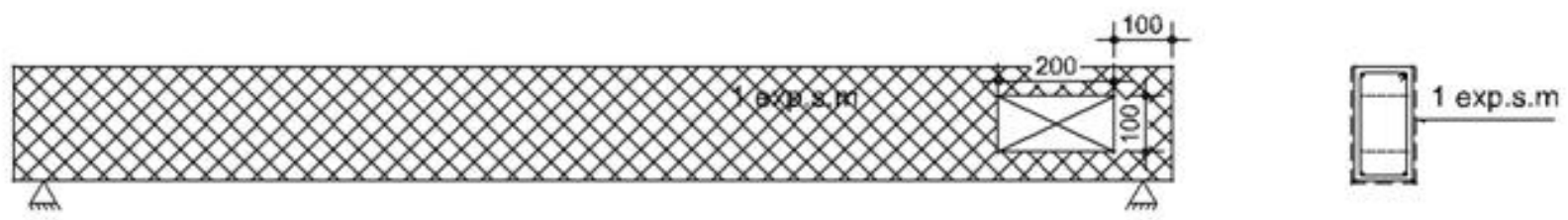

(11)
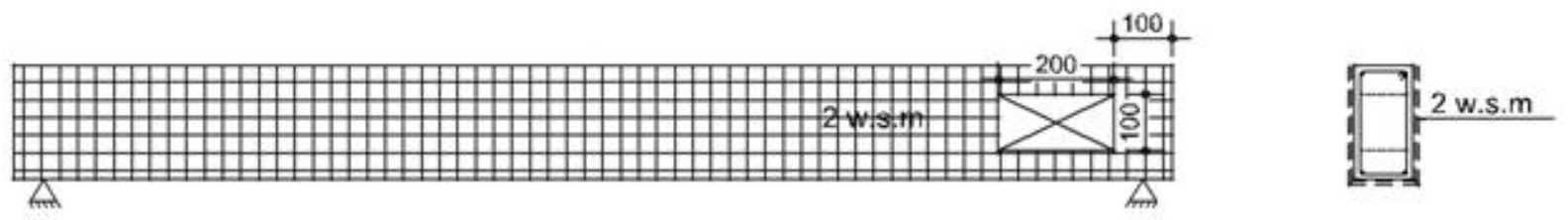

(12)
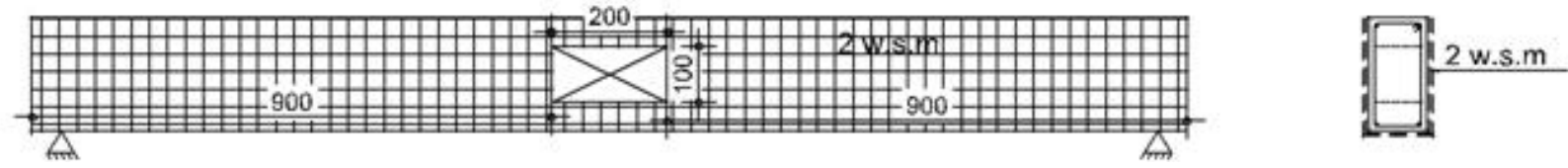
Fig. 2 Shows Reinforcement Configurations of Beams B7-B12.

\section{MATERIALS}

The properties of the used materials for producing the concrete, mortar, and concrete mixes as well as the reinforcing steel bars, steel meshes, shear connectors, and chemical admixtures are given in the following sections.

\subsection{Fine Aggregate}

Natural siliceous sand was used as the fine aggregate throughout the current research. The main tests performed on the fine aggregates to insure its compliance with ASTM requirements were:

\subsubsection{Sieve Analysis of fine aggregates according to ASTM C136-84a:}

The results of sieve analysis are shown in Table 2 and Fig. 3. While Table 3 Shows Physical and Mechanical Properties of Fine Aggregate.

Table 2: Results of Sieve Analysis Test for Sand Used.

\begin{tabular}{|l|l|l|l|l|l|l|l||}
\hline $\begin{array}{l}\text { Sieve Diameter } \\
\text { (Micrometer) }\end{array}$ & 75 & 150 & 300 & 600 & 1180 & 2360 & 5000 \\
\hline \% Passing & 2.2 & 9.5 & 21.3 & 56.9 & 83.1 & 91.6 & 98.4 \\
\hline
\end{tabular}

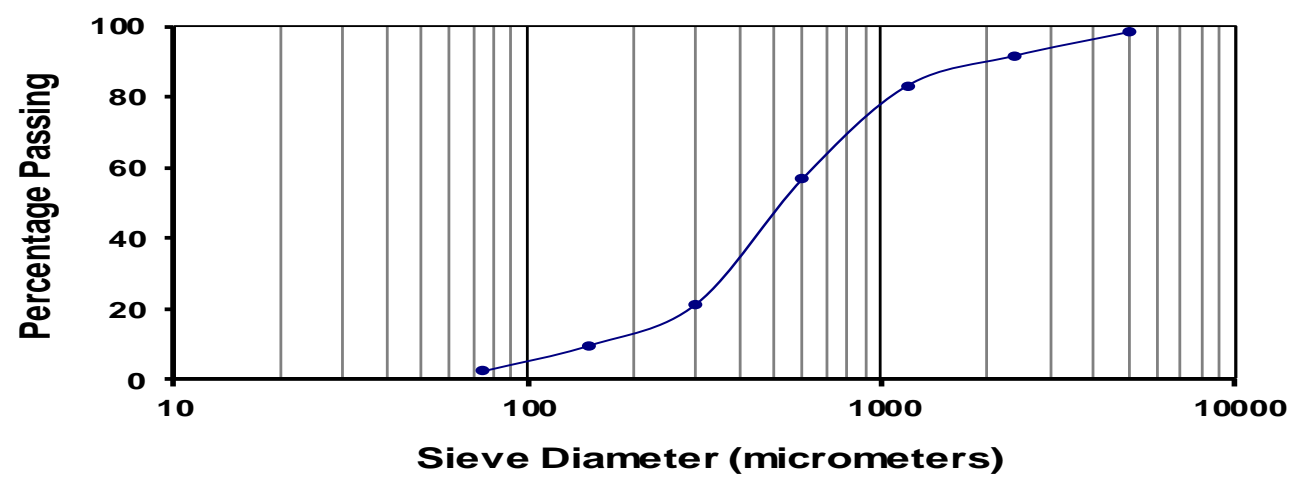

Fig. 3 Grading curve f sand used. 
Table 3 Physical and Mechanical Properties of Fine Aggregate.

\begin{tabular}{|l|l|}
\hline Property & Test results for Sand \\
\hline Specific Gravity (S.S.D) & 2.6 \\
\hline Volume Weight & 1.7 \\
\hline Voids Ratio & $30 \%$ \\
\hline Fineness Modulus & 2.91 \\
\hline Clay, Silt, and Fine Dust & $2 \%$ (by weight) \\
\hline Percent of Chloride & 0.03 (by weight) \\
\hline
\end{tabular}

\subsection{Cement}

The cement used was the ordinary Portland cement, which was provided from the Suez factory. Its chemical and physical characteristics satisfy the Egyptian Standard Specification E.S.S. 373/1991. Table (4) shows the mechanical, physical and chemical properties of the cement used.

Table (4) Mechanical, physical and chemical properties of the cement used.

\begin{tabular}{|c|c|c|}
\hline Property & Value & Limits \\
\hline Specific gravity & 3.15 & --- \\
\hline Setting time & & ----- \\
\hline Initial min. & 60 & $\begin{array}{c}\text { Not less than 45 } \\
\text { min }\end{array}$ \\
\hline Final hrs. & 5.3 & $\begin{array}{c}\text { Not more than } 10 \\
\text { hrs }\end{array}$ \\
\hline Fineness & 2870 gm / cm2 & $\begin{array}{c}\text { Not less than 2500 } \\
\text { gm /cm }\end{array}$ \\
\hline Soundness & Zero & \begin{tabular}{c} 
Not more than 10 \\
\hline
\end{tabular}
\end{tabular}

\begin{tabular}{|c|c|c|}
\hline (Expansion) & & $\mathrm{mm}$ \\
\hline 3 days & $195 \mathrm{Kg} / \mathrm{cm}^{2}$ & $\begin{array}{c}\text { Not less than } \\
183.42\end{array}$ \\
\hline 7 days & $295 \mathrm{Kg} / \mathrm{cm} 2$ & $\begin{array}{c}\text { Not less than } \\
275.13\end{array}$ \\
& & $366.84 \mathrm{Kg} / \mathrm{cm} 2$ \\
\hline 28 days & $385 \mathrm{Kg} / \mathrm{cm} 2$ & \\
\hline
\end{tabular}

\subsection{Silica fume}

To obtain high strength mortar, condensed silica fume was used to replace part of the cement used. Based on the results of the previous research (Korany 1996), replacement of $15 \%$ of cement content by weight by silica fume was used. The chemical composition of silica fume is given in Table 5 . 
Table 5: Chemical composition of silica fume

\begin{tabular}{|l|l|}
\hline Chemical & Weight percent (\%) \\
\hline \hline $\mathrm{SiO}_{2}$ & $92-94$ \\
\hline $\mathrm{Carbon}$ & $3-5$ \\
\hline $\mathrm{Fe}_{2} \mathrm{O}_{3}$ & $0.1-0.5$ \\
\hline $\mathrm{CaO}$ & $0.1-0.15$ \\
\hline $\mathrm{AL}_{2} \mathrm{O}_{3}$ & $0.2-0.3$ \\
\hline $\mathrm{MgO}$ & $0.1-0.2$ \\
\hline $\mathrm{MnO}$ & 0.008 \\
\hline $\mathrm{K}_{2} \mathrm{O}$ & 0.1 \\
\hline $\mathrm{Na}_{2} \mathrm{O}$ & 0.1 \\
\hline
\end{tabular}

\subsection{Chemical Admixtures (Super plasticizer)}

Super plasticizer complies with ASTM C494 type F, and B.S. 5075 part 3, with a specific weight of 1.2 at $20^{\circ} \mathrm{C}$ was used to provide the necessary workability for concrete and mortar. The super plasticizer's commercial name is SIKAMINT 163M. The recommended dosage is between $0.5-2 \%$ by weight of cementatous material.

\subsection{Reinforcing Steel and Steel Mesh}

\subsubsection{Reinforcing Steel Bars}

High tensile deformed steel bars of diameters $12 \mathrm{~mm}$ and $10 \mathrm{~mm}$ were used to reinforce the control beams. Tensile tests were performed on three samples of the bars. The average test results of the three samples showed the proof stress and ultimate strength of the material were $641 \mathrm{~N} / \mathrm{mm}^{2}$ and $723 \mathrm{~N} / \mathrm{mm}^{2}$ respectively. The stressstrain relationship for the reinforcing steel bars are shown in Figure 4.

Mild steel stirrups of diameter $8 \mathrm{~mm}$ were used as shear reinforcement for the control beam. The material has nominal yield stress of $240 \mathrm{~N} / \mathrm{mm}^{2}$. Tensile test was not performed on this type of steel.

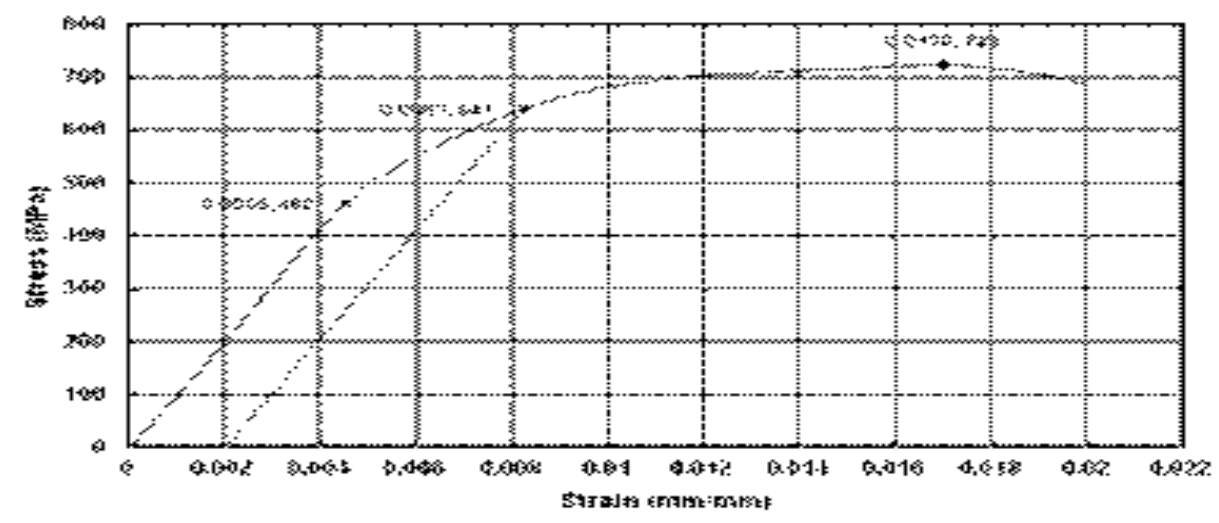

Fig.4: Stress-strain relationship for the reinforcing steel bars 


\subsubsection{Steel Meshes}

\subsubsection{Expanded metal mesh}

This type of mesh is made from sheets of steel has a thickness of $1.25 \mathrm{~mm}$. The diamond size is $16.5 \times 31 \mathrm{~mm}$. The proof stress is equal to $250 \mathrm{~N} / \mathrm{mm}^{2}$ and its ultimate strength is $350 \mathrm{~N} / \mathrm{mm}^{2}$, while its modulus of elasticity equal to $120 \mathrm{KN} / \mathrm{mm}^{2}$. The mesh has a weight of $1500 \mathrm{gm} / \mathrm{m}^{2}$. Fig.5 shows this type of mesh.

\subsubsection{Welded galvanized wire mesh}

This type of mesh is made from welded galvanized wires of diameter $0.7 \mathrm{~mm}$. The size of opening is $12.5 \times 12.5 \mathrm{~mm}$. The proof stress is equal to $400 \mathrm{~N} / \mathrm{mm}^{2}$ and its ultimate strength is $600 \mathrm{~N} / \mathrm{mm}^{2}$, while its modulus of elasticity equal to $170 \mathrm{KN} / \mathrm{mm}^{2}$. The mesh has a weight of $450 \mathrm{gm} / \mathrm{m}^{2}$. Fig.6 shows this type of mesh. Fig. 6 shows welded wire mesh.

\subsubsection{Polypropylene fiber e-300}

Fig. 7 shows Polypropylene fiber e-300 used as $1200 \mathrm{gm} . / \mathrm{m}^{3}$

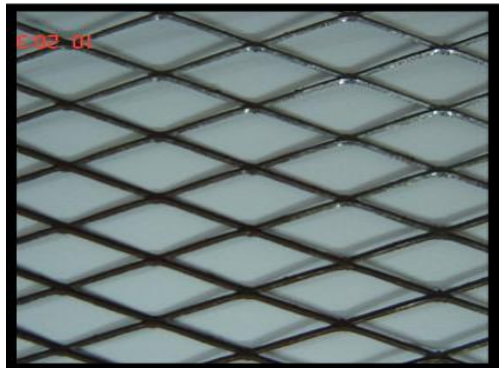

Fig.5: Expanded metal mesh.

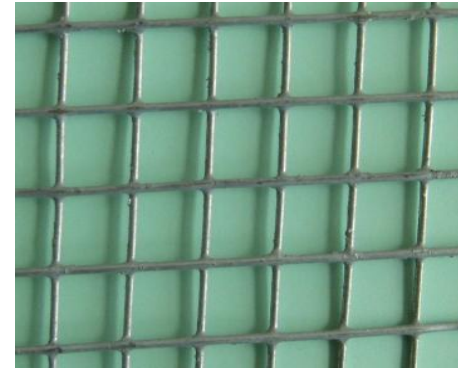

Fig.6: Welded wire mesh.

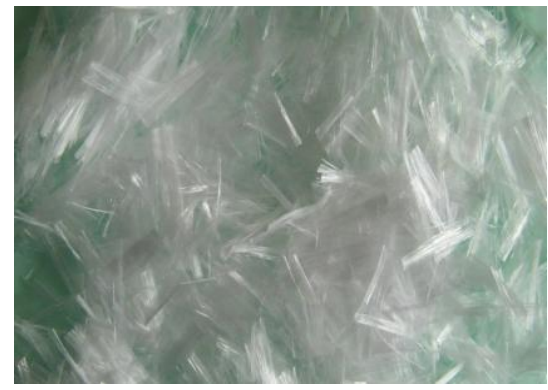

Fig. 7 Polypropylene fiber e-300

\section{Test procedure}

All test specimens were tested under bending machine. The test was conducted under four lines loadings. The specimen was centered on the test rig, where the span between the two supports was kept constant at $1900 \mathrm{~mm}$. Two dial gauges were placed under the test specimens as shown in the previous figures. on the specimen exactly at the center. Concurrently, the beam deflection was determined by recording the dial gauge readings at each load increment. Cracks were traced and marked throughout the side of the specimen. The first crack-load of each specimen, crack propagation, and failure mode was recorded. The load was increased until failure using flexural testing machine $100 \mathrm{KN}$ as shown in Fig.8. 


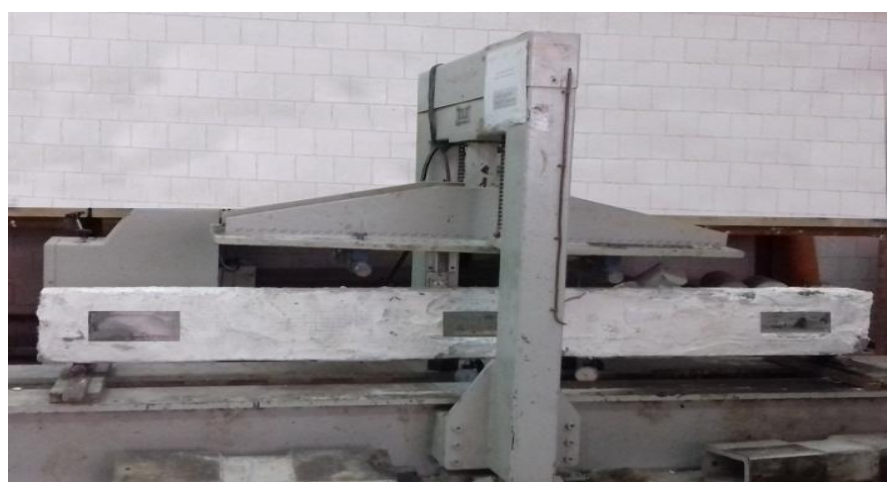

Figure 8: Flexural Testing Machine ELE 100 k.N.

\section{Analysis and Discussions of Results}

Table 6: First crack, serviceability, ultimate loads, ductility ratios and energy absorption. properties of all the tested beams.

\begin{tabular}{|r|r|r|r|r|r|r|r|r|r|}
\hline $\begin{array}{r}\text { Volume } \\
\text { fraction, } \\
\%\end{array}$ & $\begin{array}{r}\text { Neam } \\
\text { No. }\end{array}$ & Volume & F.C.,KN & $\begin{array}{r}\text { Pser } \\
\text { fraction, \% }\end{array}$ & $\begin{array}{r}\text { P.ult. } \\
\text { vice, } \\
\text { KN }\end{array}$ & $\begin{array}{r}\text { Deflection } \\
\text { at } \\
\text { FN }\end{array}$ & $\begin{array}{r}\text { Max. } \\
\text { deflection, } \\
\mathrm{mm}\end{array}$ & $\begin{array}{r}\text { Ductilit } \\
\mathrm{y} \\
\text { Ratio }\end{array}$ & $\begin{array}{r}\text { Energy.abs } \\
\text { KN.mm }\end{array}$ \\
\hline 2.769 & B1 & 2.769 & 24 & 15 & 63 & 7.9 & 15.1 & 1.911 & 1803.85 \\
\hline 2.992 & B2 & 2.992 & 35 & 7.5 & 58 & 8.6 & 23.3 & 2.71 & 815.035 \\
\hline 3.03 & B3 & 3.03 & 30 & 30 & 54.3 & 7.55 & 16.6 & 2.20 & 512.045 \\
\hline 3.049 & B4 & 3.049 & 10 & 7.5 & 14.7 & 5.7 & 13.5 & 2.37 & 138.015 \\
\hline 2.83 & B5 & 2.83 & 10 & 7 & 16.4 & 8.7 & 19.4 & 2.23 & 185.21 \\
\hline 2.957 & B6 & 2.957 & 18 & 16 & 22 & 8.49 & 15.99 & 1.88 & 221.09 \\
\hline 3.585 & B7 & 3.585 & 15 & 13 & 25 & 8.59 & 20.29 & 2.36 & 308.675 \\
\hline 3.069 & B8 & 3.069 & 15 & 15 & 25 & 7.6 & 22 & 2.89 & 321.8 \\
\hline 2.81 & B9 & 2.81 & 13 & 14 & 18 & 6.5 & 17.9 & 2.75 & 230.16 \\
\hline 3.03 & B10 & 3.03 & 15 & 20 & 28 & 6.21 & 18 & 2.89 & 305.15 \\
\hline 2.79 & B11 & 2.79 & 20 & 23 & 28 & 5.8 & 13.15 & 2.27 & 243.925 \\
\hline $2 . .79$ & B12 & $2 . .79$ & 45 & 32 & 59 & 11.57 & 23.17 & 2.00 & 895.335 \\
\hline
\end{tabular}
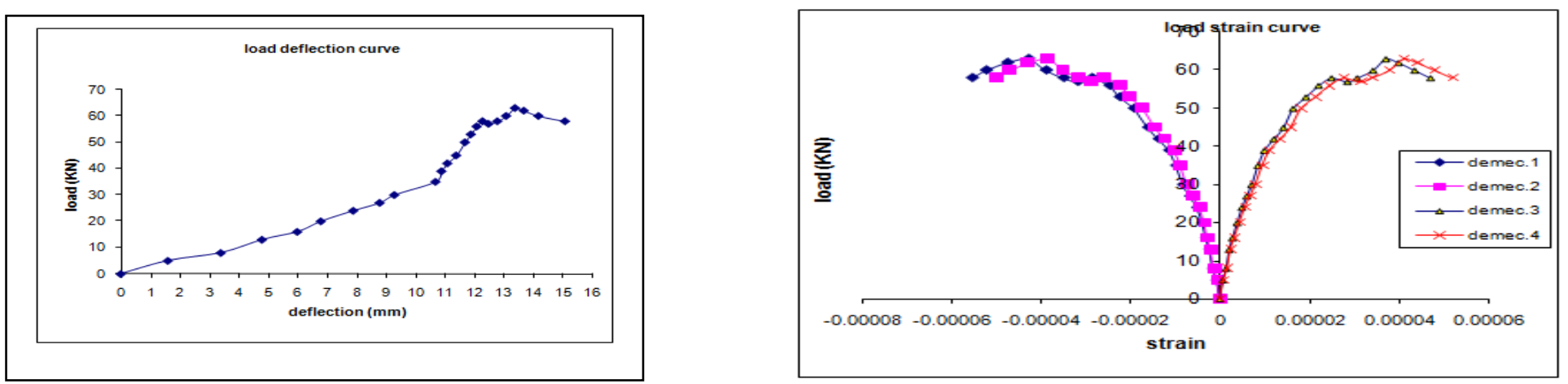
Fig.9 Load deflection Curve of B1

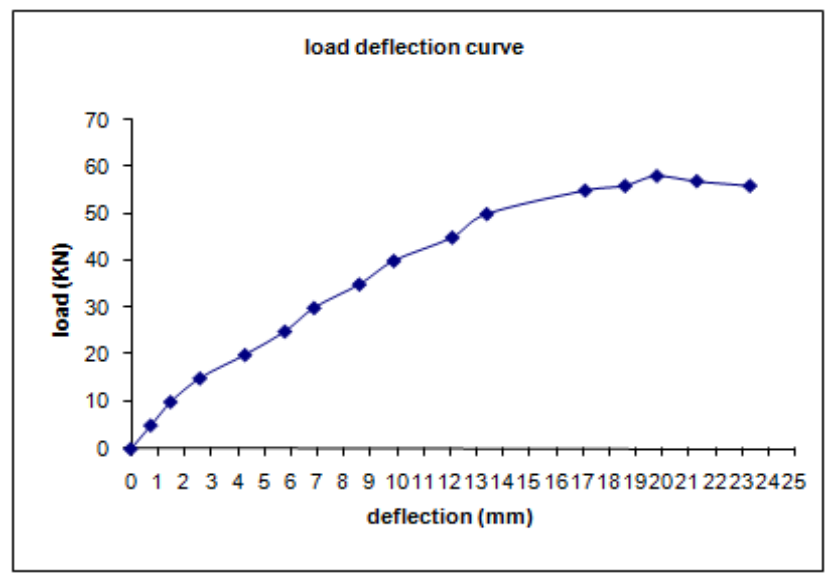

Fig.11 Load deflection Curve of B2

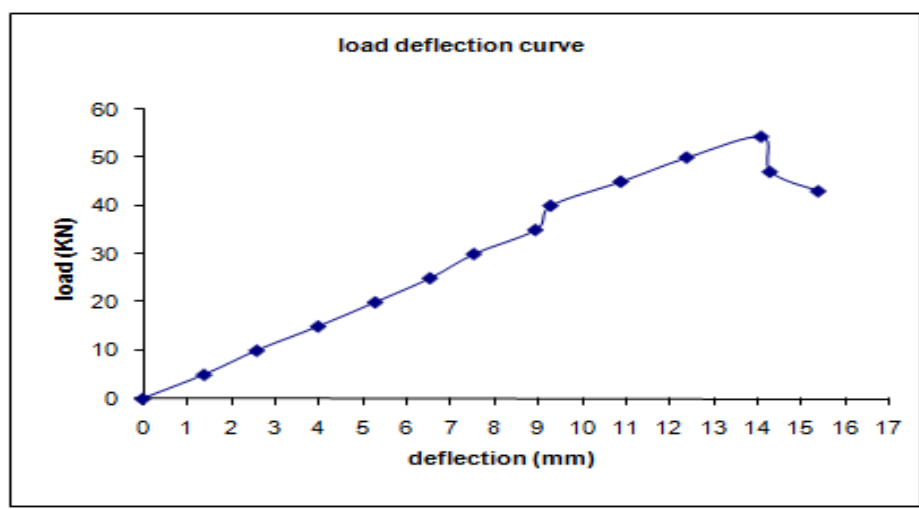

Fig.13 Load deflection Curve of B3

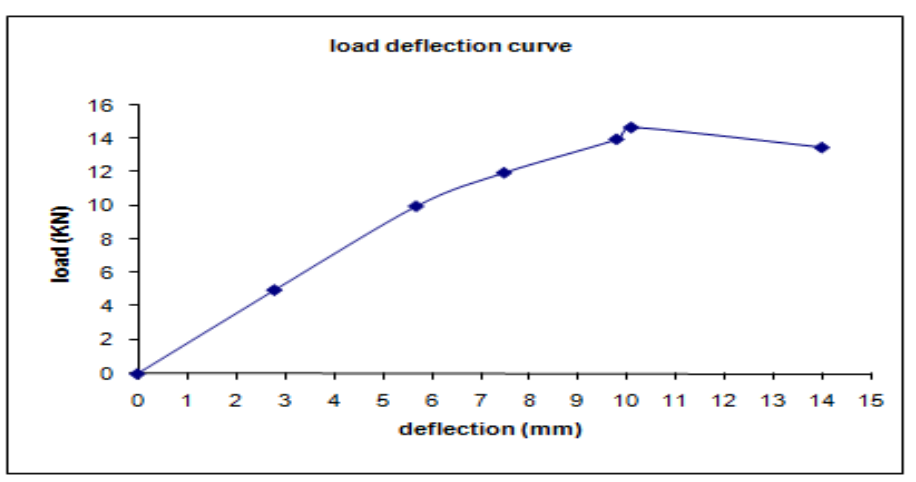

Fig.15 Load deflection Curve of B4
Fig.10 Load Strain Curves of B1

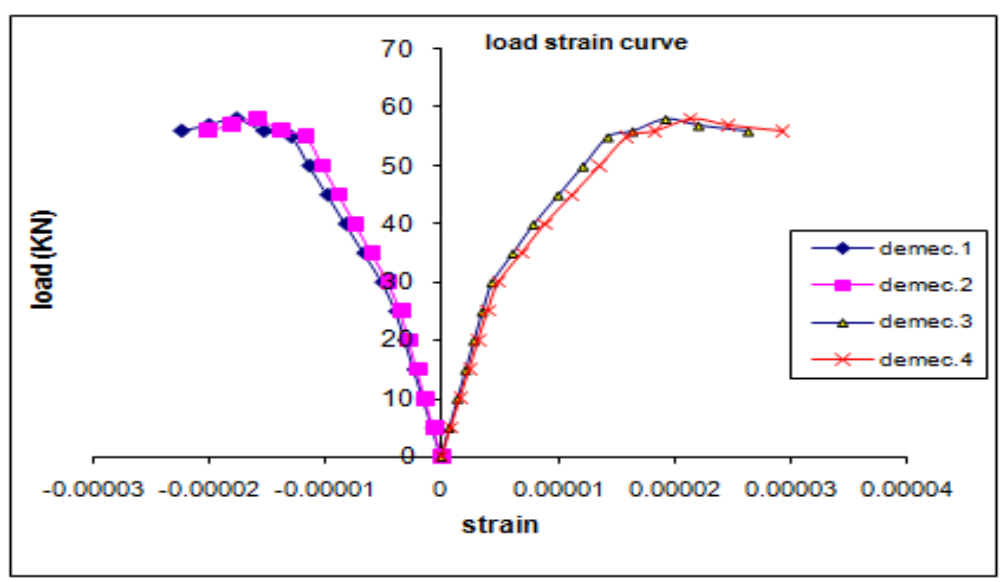

Fig.12 Load Strain Curves of B2

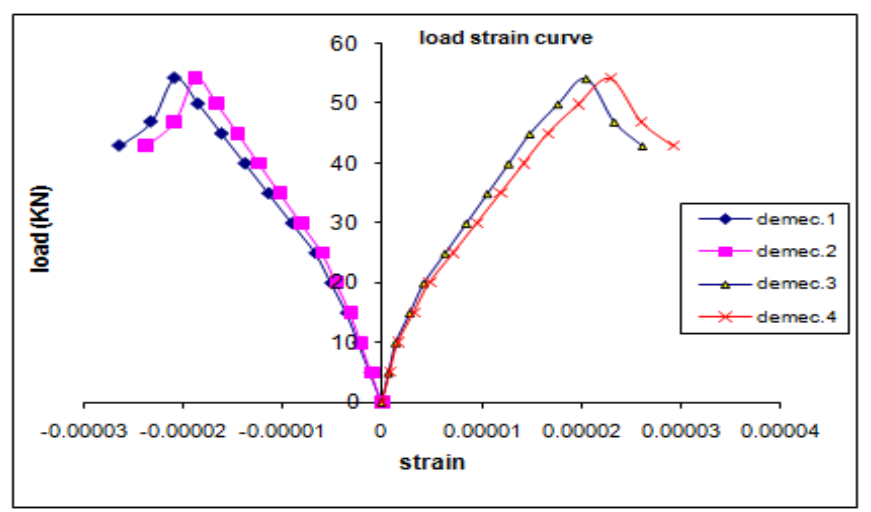

Fig. 14Load Strain Curves of B3

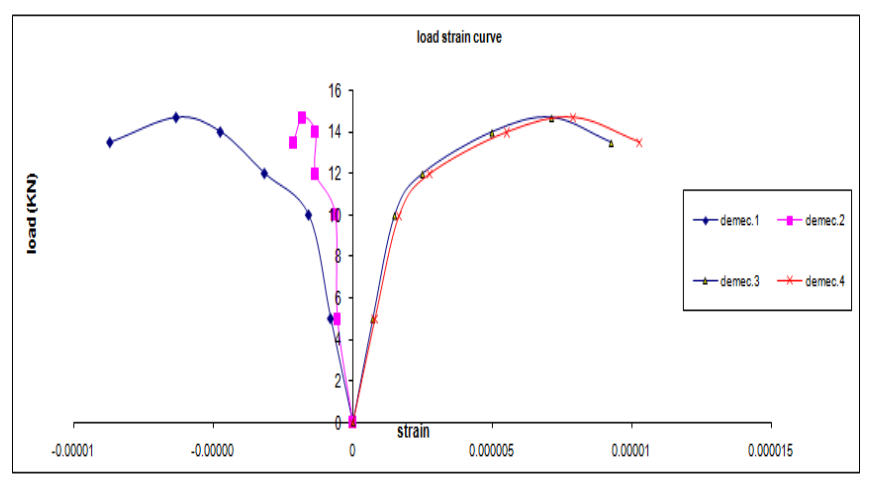

Fig. 16 Load Strain Curves of B4 


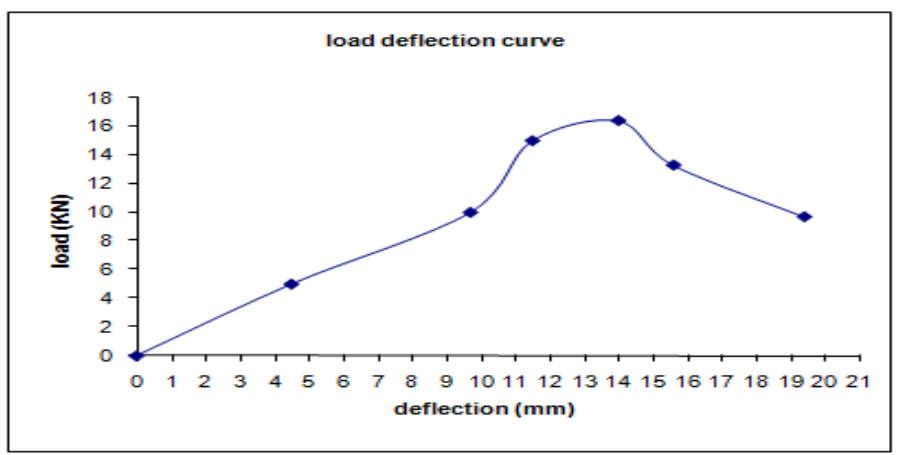

Fig.17 Load deflection Curve of B5

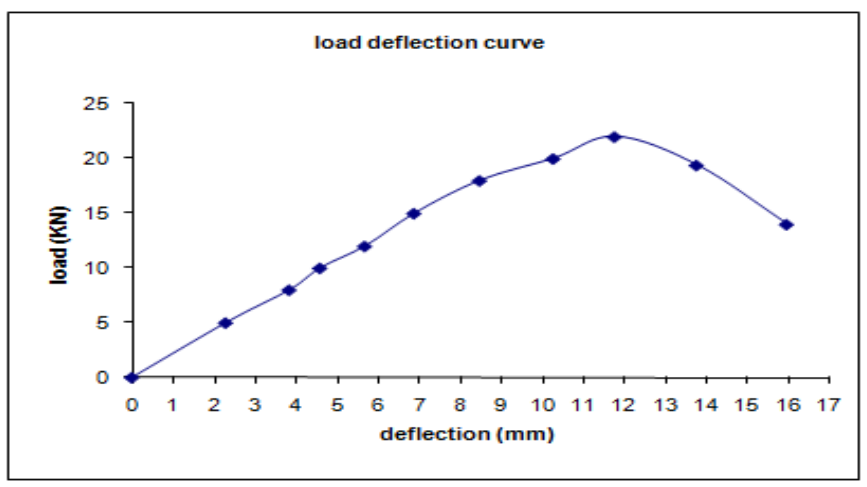

Fig.19 Load deflection Curve of B6

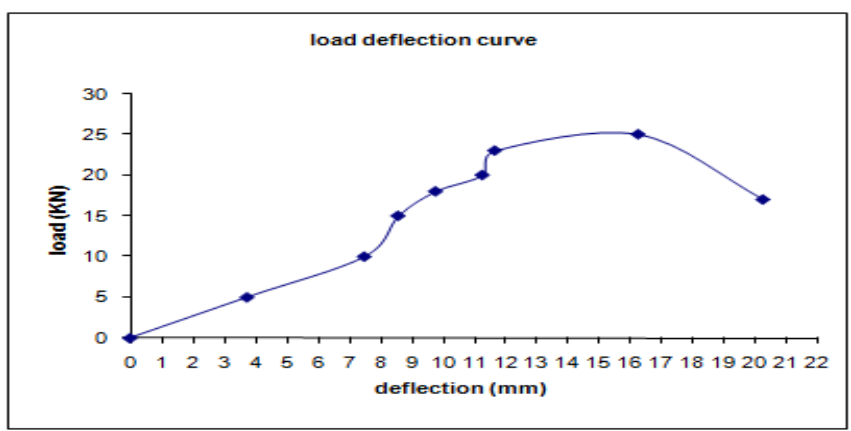

Fig.21 Load deflection Curve of B7

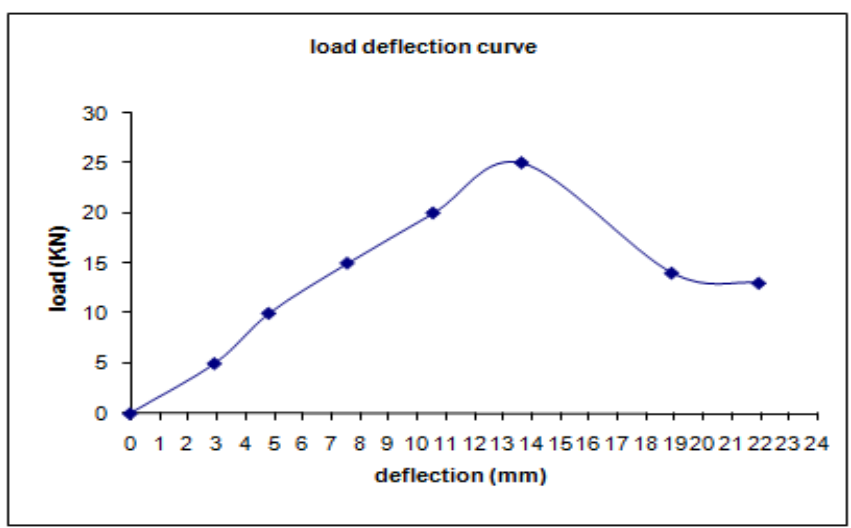

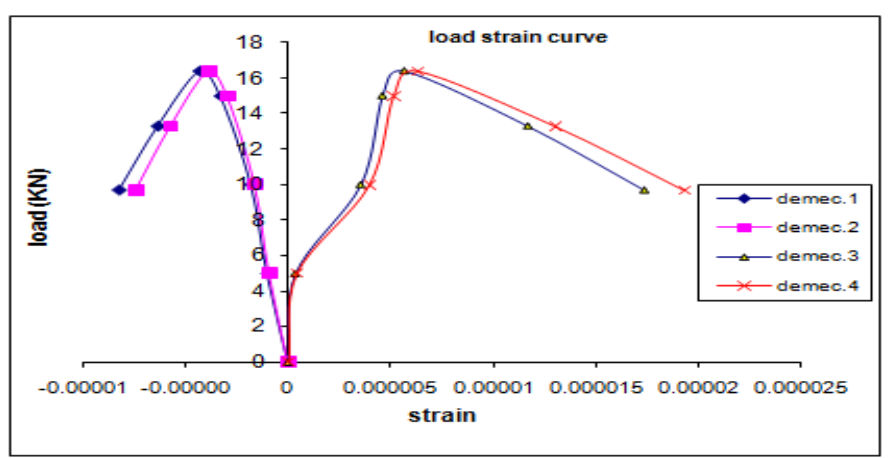

Fig.18 Load Strain Curves of B5

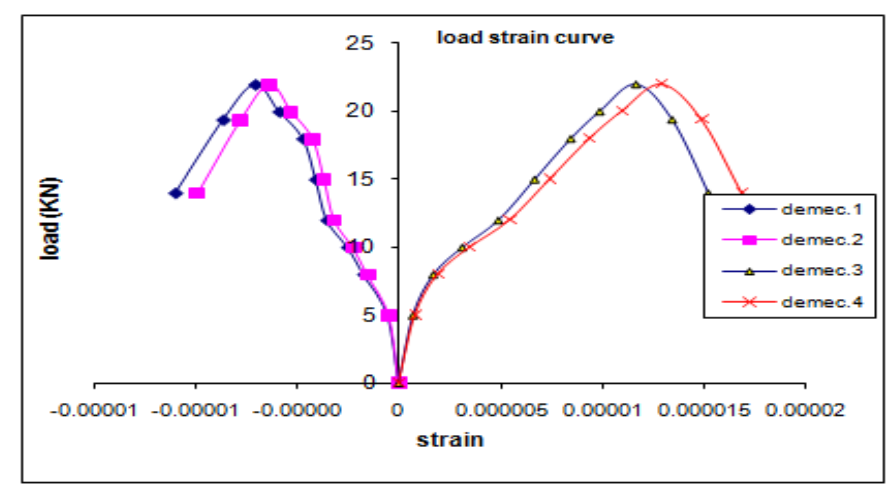

Fig.20 Load Strain Curves of B6

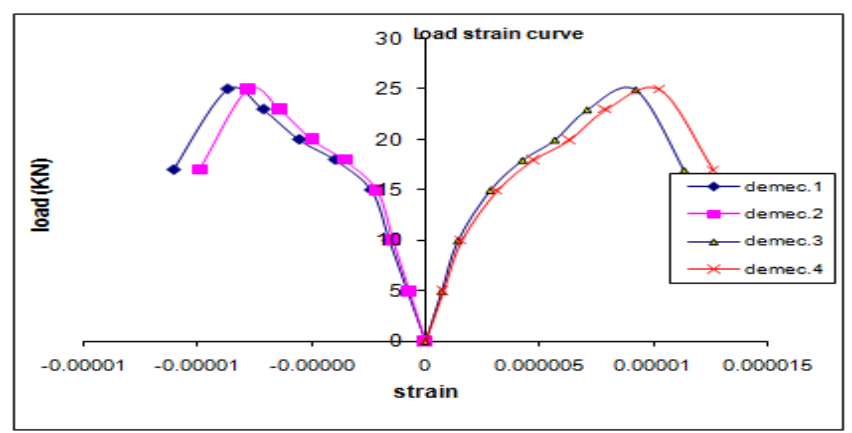

Fig. 22 Load Strain Curves of B7

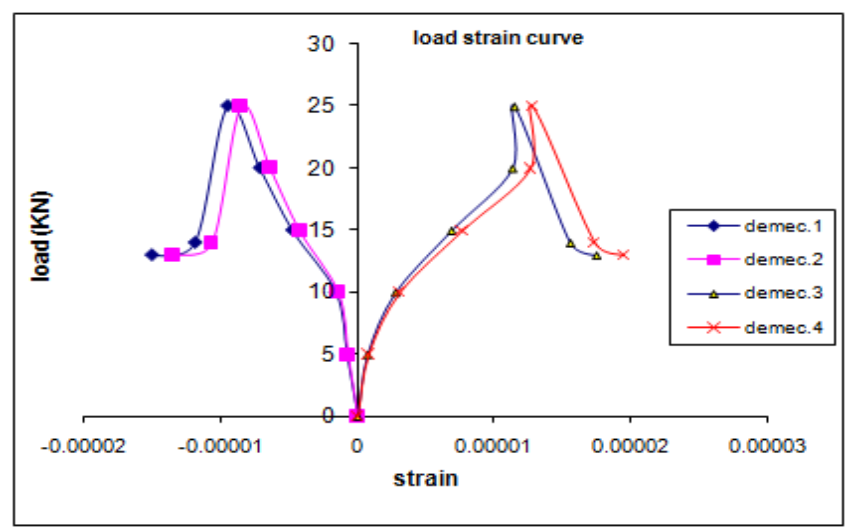


Fig.23 Load deflection Curve of B8

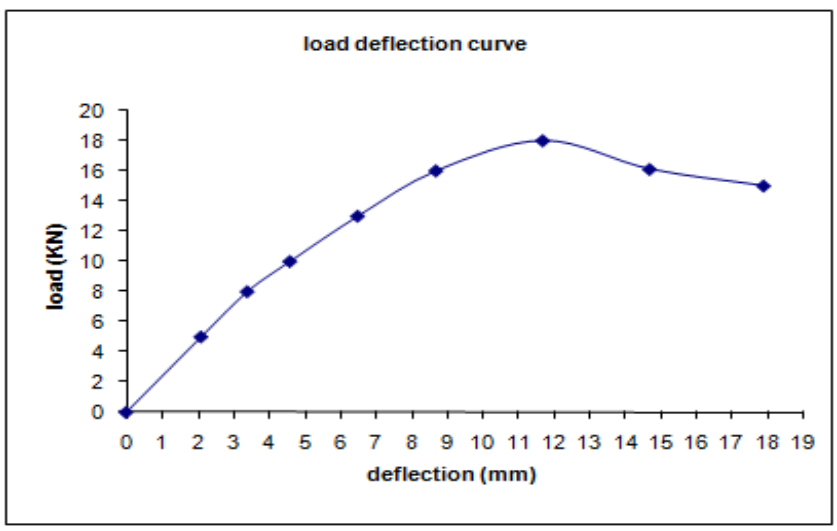

Fig.25 Load deflection Curve of B9

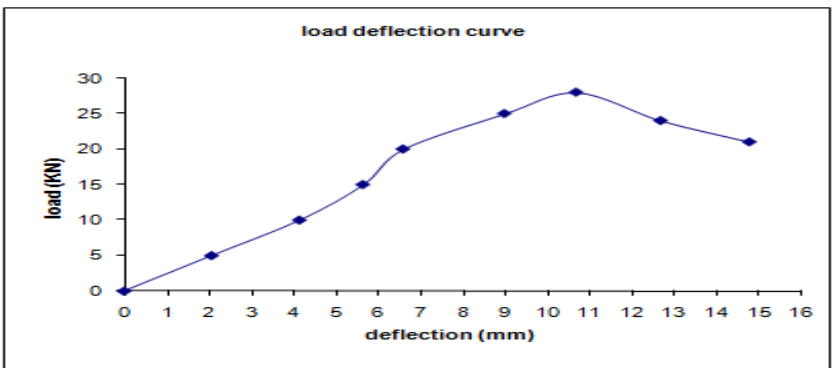

Fig.27 Load deflection Curve of B10

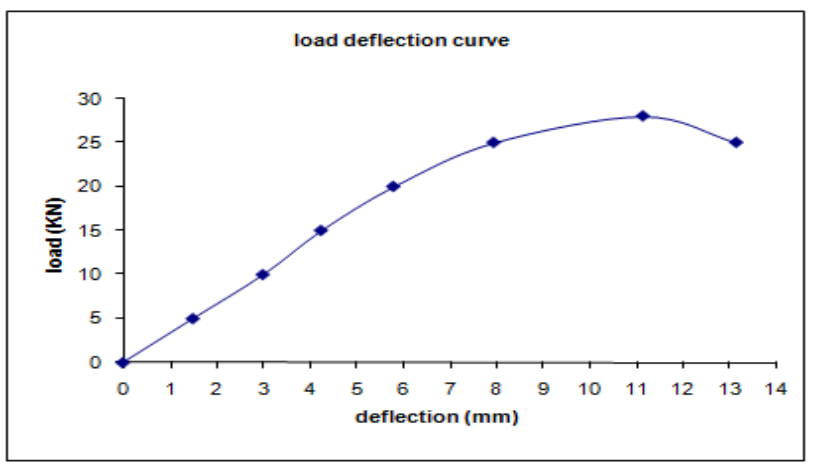

Fig.29 Load deflection Curve of B11

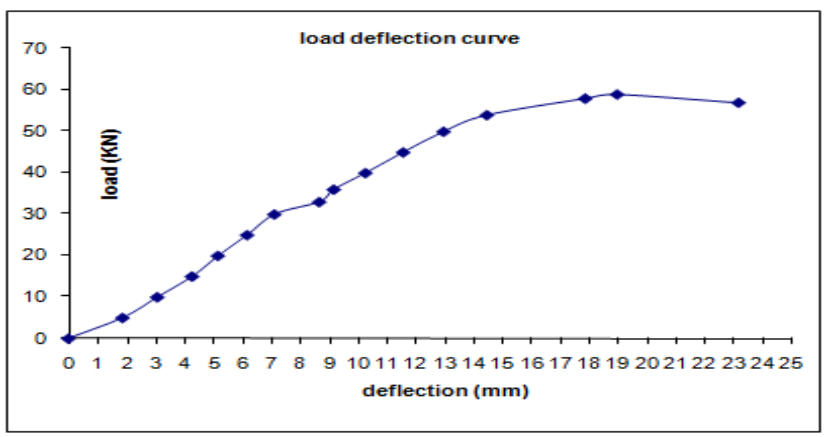

Fig.31 Load deflection Curve of B12
Fig. 24 Load Strain Curves of B8

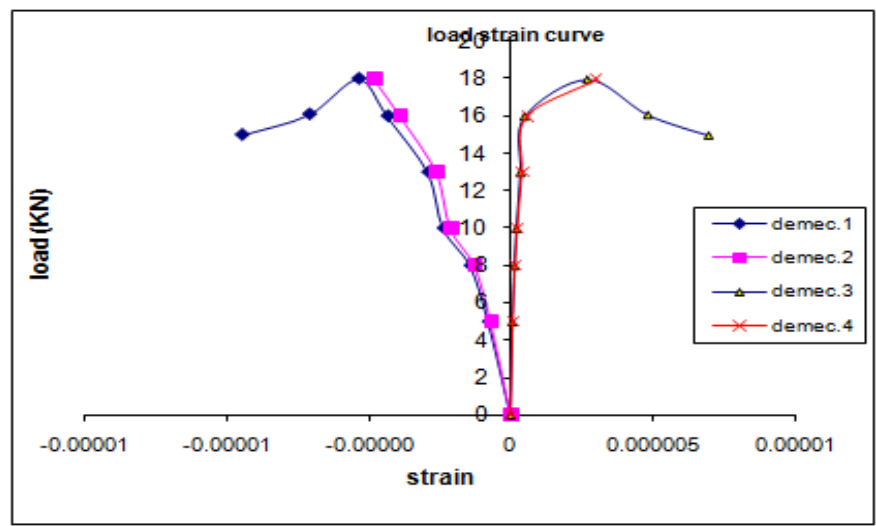

Fig. 26 Load Strain Curves of B9

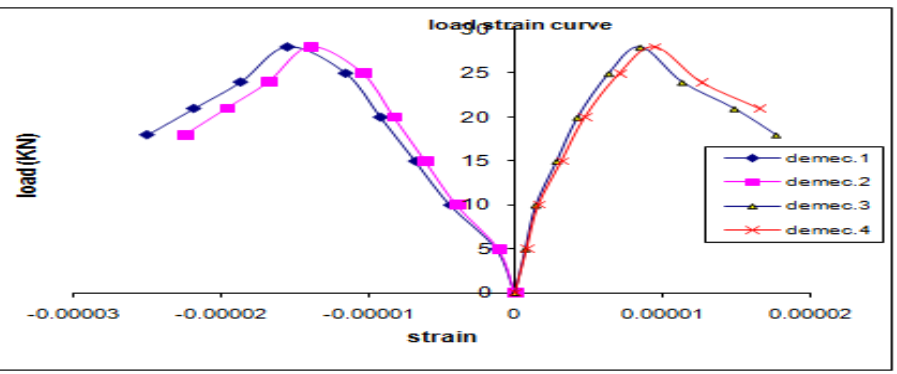

Fig. 28 Load Strain Curves of B10

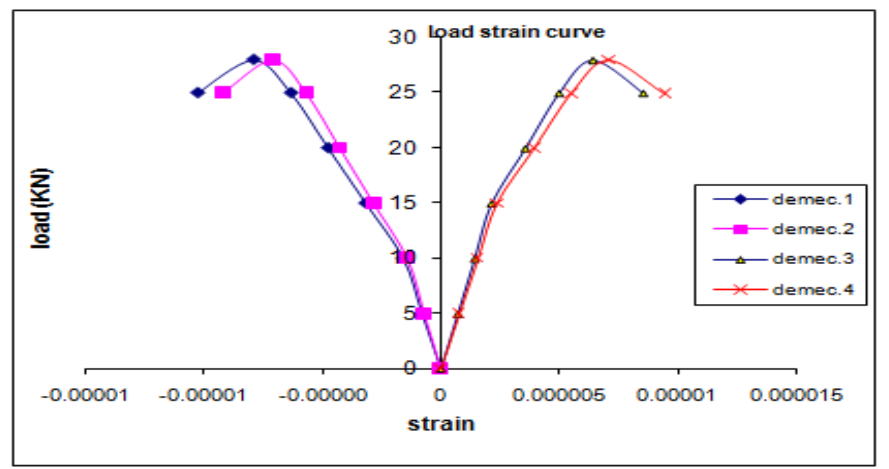

Fig. 30 Load Strain Curves of B11

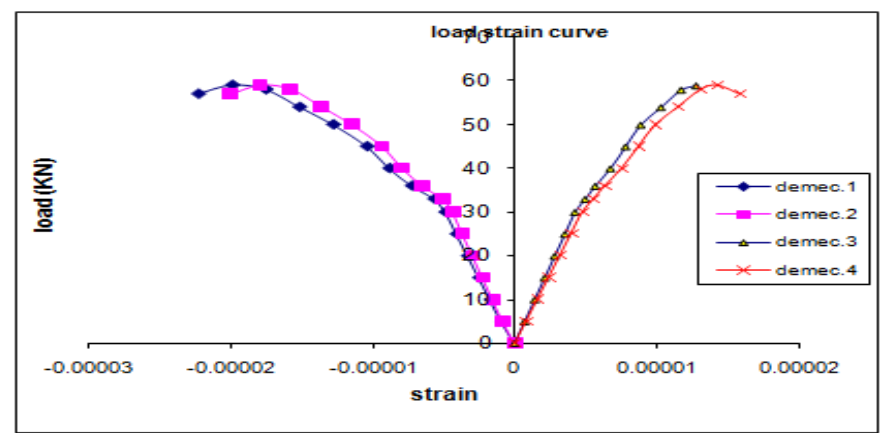

Fig. 32 Load Strain Curves of B12 


\section{1 Deformation Characteristics}

The plotted central deflection of the test specimens against the applied load is shown in Figures for beams B1B12 respectively. It can be seen from these Figures that the load-deflection relationship of the test specimens can be divided into three stages as follows:

a) Elastic behavior until the first cracking. The load-deflection relationship in this stage is linear. The slope of the load-deflection curve in this stage varies with different types of the test specimens. The end of this stage is marked

by the deviation from linearity. The extent of this stage varied with the type and number of layers of the steel meshes.

b) In the second stage, the slope of the load-deflection curve changes gradually due to the expected reduction in the specimens' stiffness as the result of multiple cracking. The gradient of the load-deflection curve increases with the increase of the volume fraction of the reinforcement.

c) In the third stage, large plastic deformation occurred as the result of yielding of the reinforcing bars and the steel meshes employed in strengthening and repairing of failed beams. This stage was terminated by failure of the test specimens.

The load-deflection relationship for beams without openings, B1 and B2 was linear up to a load of $24 \mathrm{kN}$ and 35 $\mathrm{KN}$ respectively after which the relation became nonlinear. For this group of specimens, the transition from the second to the third stages, as explained before, was not distinct as shown in Figs. 4.1 and 4.3 while the first crack load occurred at a load equal $30 \mathrm{KN}$ for beam B3 due to central opening $100 \mathrm{~mm} \times 200 \mathrm{~mm}$. At failure, the midspan deflection reached $15.1 \mathrm{~mm}$ and $23.3 \mathrm{~mm}$ for beams B1 and B2 respectively. Beam B3 with central opening, the deflection at first crack loads was $7.55 \mathrm{~mm}$ while the maximum deflection was $16.6 \mathrm{~mm}$. For beams B4, B5, B6, $B 7$ having three openings the deflection at first crack loads were $5.7 \mathrm{~mm}, 8,7 \mathrm{~mm}, 8.49 \mathrm{~mm}, 8.58 \mathrm{~mm}$ respectively while the deflections at failure were $13.5 \mathrm{~mm}, 19.4 \mathrm{~mm}, 15.49 \mathrm{~mm}, 20.29 \mathrm{~mm}$ respectively. For beams B8 and B9 having two openings at both ends of the beam the deflection at first crack loads were $7.6 \mathrm{~mm}, 6.5 \mathrm{~mm}$ respectively while the deflections at failure were $22 \mathrm{~mm}, 17.9 \mathrm{~mm}$ respectively. For beams B10 and B11 having one opening at their ends of the beam the deflection at first crack loads were $6.21 \mathrm{~mm}, 5.8 \mathrm{~mm}$ respectively while the deflections at failure were $18 \mathrm{~mm}, 13.15 \mathrm{~mm}$ respectively. For beam B12 with one central opening and strengthening with two layers of welded steel mesh, the deflection at first crack loads was 11.57, while the recorded maximum deflection was $23.17 \mathrm{~mm}$.

\subsection{Behavior of ferrocement beams with openings}

As described in chapter three beams were tested under four lines loadings and the deflection at each load increment was recorded at two points on the tested beams to draw the load-deflection curves; crack initiation and propagation was also observed for each test specimen. The effect of the parameters under investigation on the ultimate moment, maximum deflection at ultimate load, ductility ratio, energy absorption, and cracking behavior are discussed in the following sections.

Fig. 33 shows comparison of first crack loads for all the tested beams while Fig. 4.26 shows comparison of all serviceability loads of all tested beams.

\subsubsection{Ultimate Load}

It is clear from Table 4.1 that employing welded galvanized steel mesh, fiber glass mesh and expanded metal mesh in strengthening and repairing of beams with openings beams B3-B12 is very effective in increasing their ultimate load than the other reinforcements formation. The ultimate load of beam B3, volume fraction of 
reinforcement of reinforcement $3.03 \%$ is much higher than that of beam B3 with $108.6 \%$ increase. It is interesting to note that the ultimate load of beam B6 which strengthening of three layers welded steel, $\mathrm{Vr}$ equal $2.96 \%$ is greater than that of beam B6 previously tested without strengthening with $122.9 \%$ increase. The ultimate load of beam B12 with central opening which strengthening with two layers of welded steel mesh achieved 236\% compared with that of previously tested B12 without strengthening. Fig. 32 emphasizes comparison of all ultimate loads of all tested beams.

\subsubsection{Deflection and Ductility Ratio}

All tested beams with openings showed typical three-stage load versus mid-span deflection relationship. Under initial loading the load-deflection response was linear up to cracking load. The second stage is defined by cracking section behavior with the steel reinforcement behaving linear elastic. Transition into third phase of behavior is marked by yielding of the tensile reinforcement and non-linear material behavior. After yielding of tension steel, beam behavior is defined by large increase in deformation with little increase in applied load. All tested beams showed large deflection at ultimate loading, which is an indication of high ductility. Table 4.1 summarized comparison of the serviceability loads based according to span/250. It is interesting to note that higher serviceability loads could be obtained for beams with openings in series $2,3,5$ and 6.

It is interesting to note from Table7 that the highest ductility ratio was found to be 2.9 for beam B10. Fig. 37 shows comparison of ductility ratios of all tested beams.

\subsection{Energy Absorption}

The experimental results given in Table 7proved that as the volume fraction for beams increase, energy absorption increased also. It is interesting to note from Table 7 that the highest energy absorption was found to be 1803.85 KN.mm for beam B1 Energy absorption for beam B12 reached 895.34 KN.mm. Fig. 34 shows comparison of energy absorption of all tested beams.

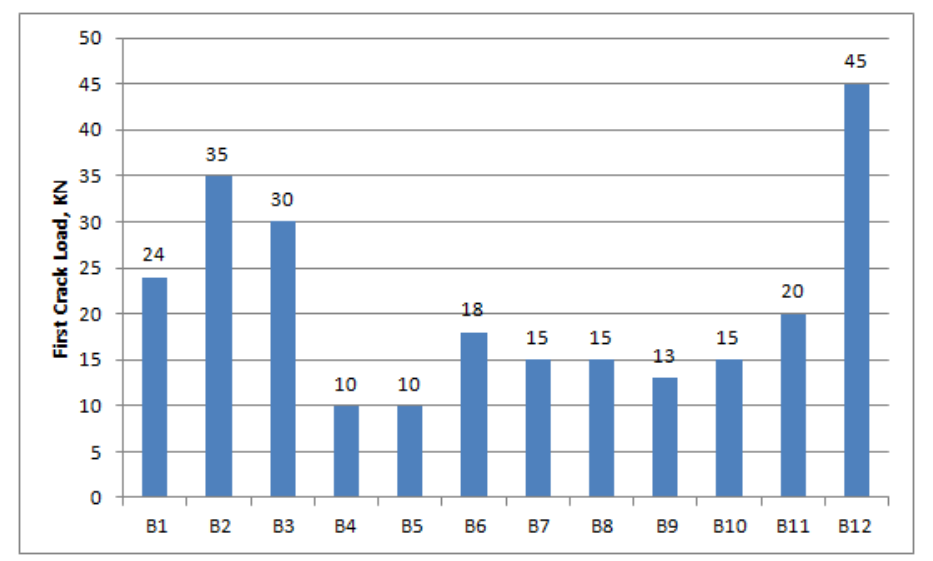

Figure 33: First crack load curve for all tested beams

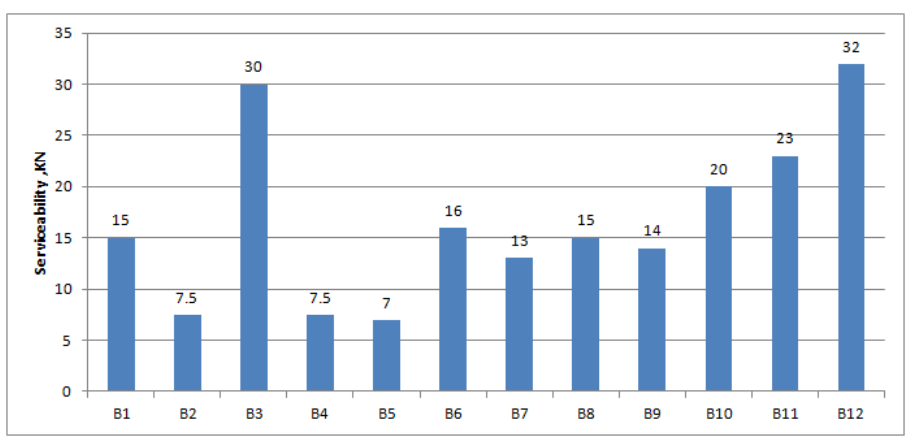

Figure 34: serviceability curve for all tested beams

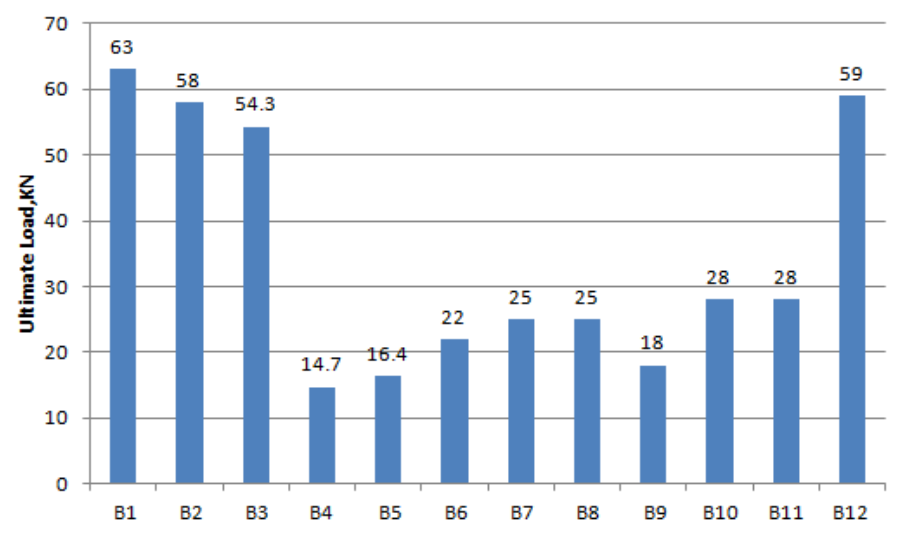

Figure 35: Ultimate Load for $r$ all tested beams. 


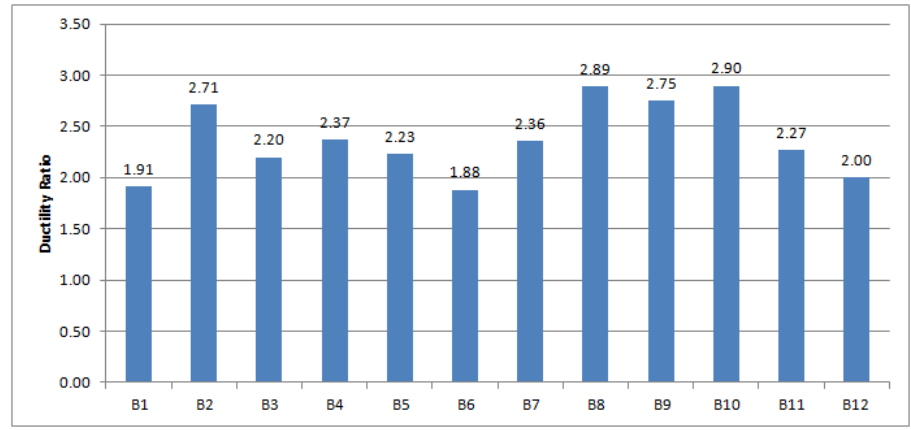

Figure 37: Ductility Ratio for all tested beams

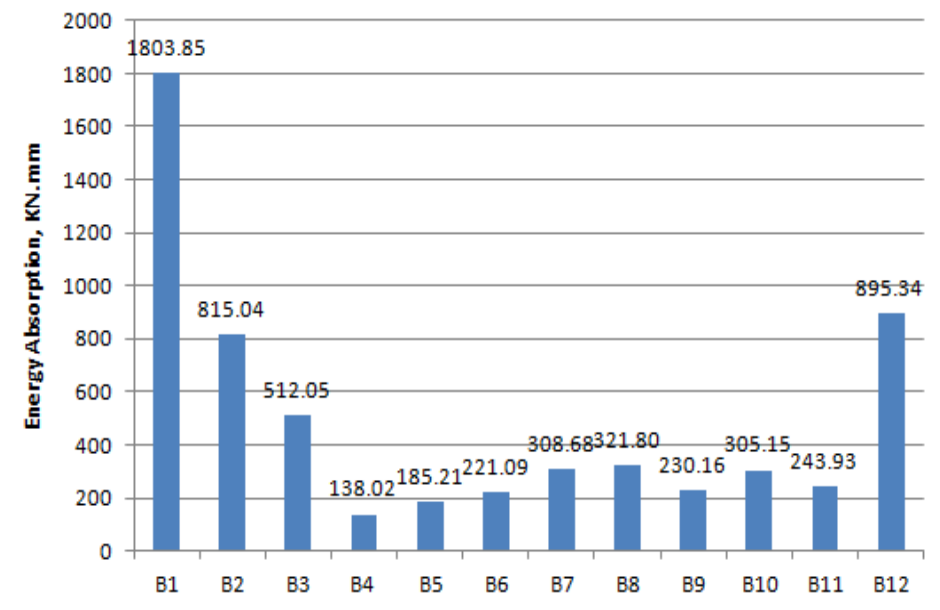

Figure 36: Energy Absorption for all tested beams.

\section{Failure Modes}

For all series designation of all the tested beams flexural failure occurred. Failure of the test specimens occurred due to reaching the ultimate stress of the reinforcing steel mesh. However, none of mesh bars was ruptured, which indicates that the strain in the steel mesh did not reach the ultimate strain of the steel mesh. After the end of each test, the specimen was removed from the testing machine and the mortar cover was removed to expose the reinforcing steel mesh. The visual investigation of the steel mesh confirmed that none of the bars has ruptured. The reinforcing steel meshes did not rupture for this designation. Cracks differed in width, number, and propagation directions according to the physical properties of each designation. In the next section the crack patterns and distributions are discussed for each designation separately.

\subsection{Cracking Patterns}

Figs. 35-46 show side views of crack patterns of all the tested beams with and without openings. Figs. 35-46 show the tensile cracks of all the tested beams. For designation (1), flexural cracks developed near the mid-span of the specimens of this designation. With the increase of the load, the cracks propagated vertically and new flexural cracks were developed rapidly. As the specimens approached their failure load, the cracks started to propagate wider. The crack width was observed; it was observed that the cracks were very wide as result of employing steel bars.

For designation beams 4, 5, 6 and 7, it is interesting to note that vertical flexural cracks started to develop close to the center of the span. As the load increased, more cracks started to develop and the crack at mid-span started to propagate vertically towards the top surface of the specimen, while most of the developed cracks did not continue propagating. This could be attributed to the effect of steel mesh in controlling the crack width. It is interesting to note that very fine vertical cracks were developed than the previous designation and the cracks were uniformly distributed along the middle $2 / 3$ of the span. The observed crack widths were much less than those of designation. This could be attributed to the effect of steel mesh in controlling the crack width. For beams B1, B5, B6, B9, B11 and B12 which were strengthened with two layers of welded steel mesh. 
B1

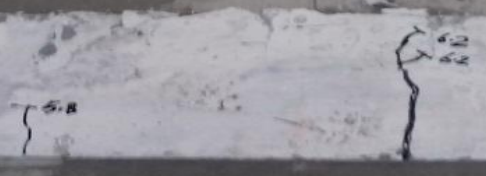

Figure 38: Cracking pattern of Beam B1

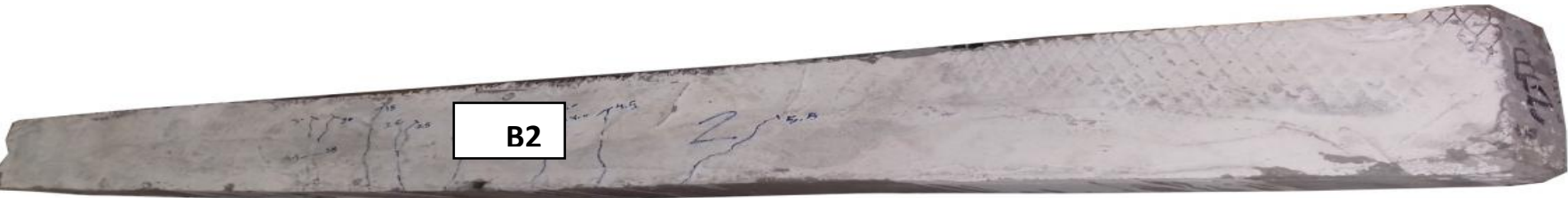

Figure 39: Cracking pattern of Beam B2

B3

Figure 40: Cracking pattern of Beam B3

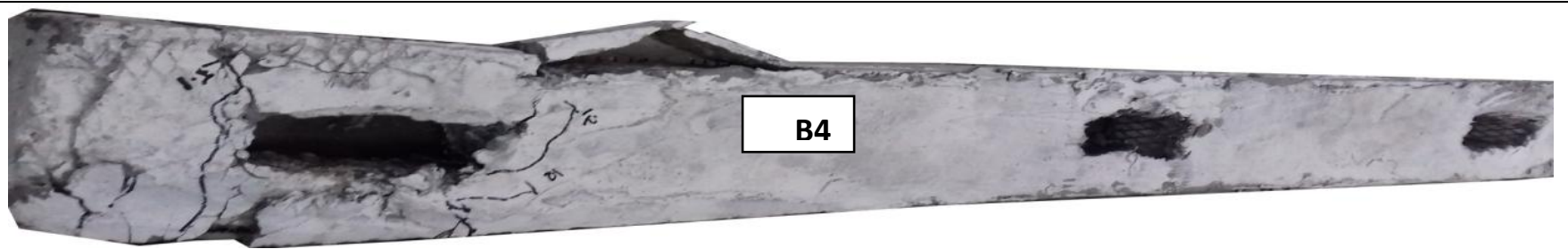

Figure 41: Cracking pattern of Beam B4

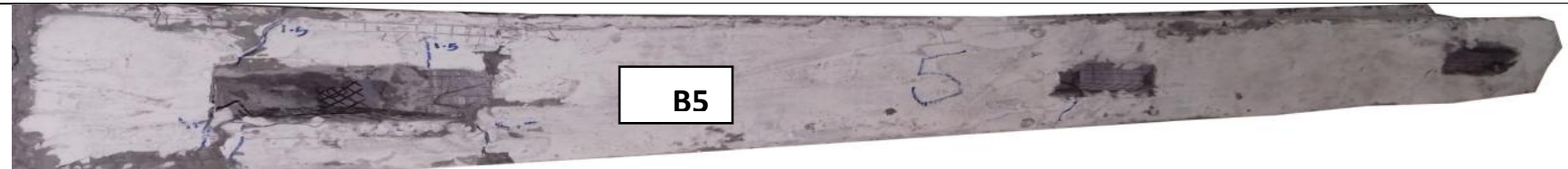

Figure 42: Cracking pattern of Beam B5

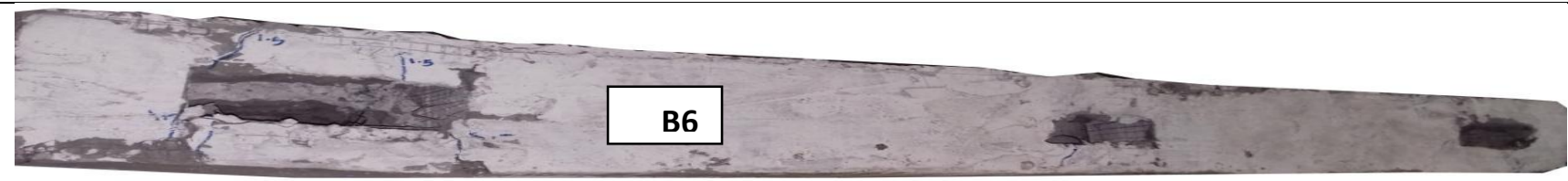

Figure 43 Cracking pattern of Beam B6 


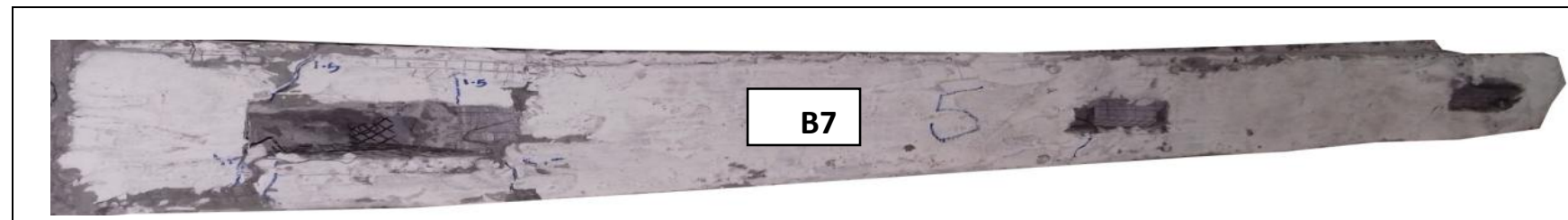

Figure 44 Cracking pattern of Beam B7

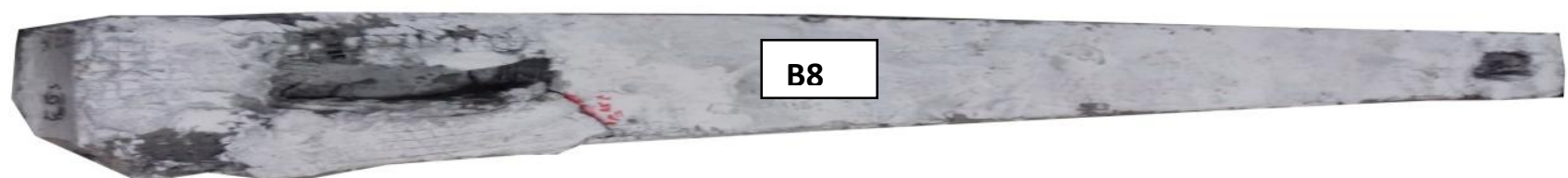

Figure 45: Cracking pattern of Beam B8

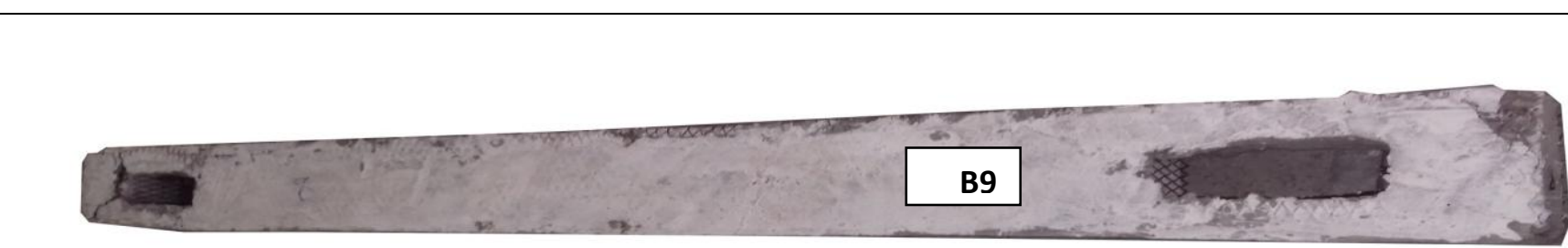

Figure 46: Cracking pattern of Beam B9

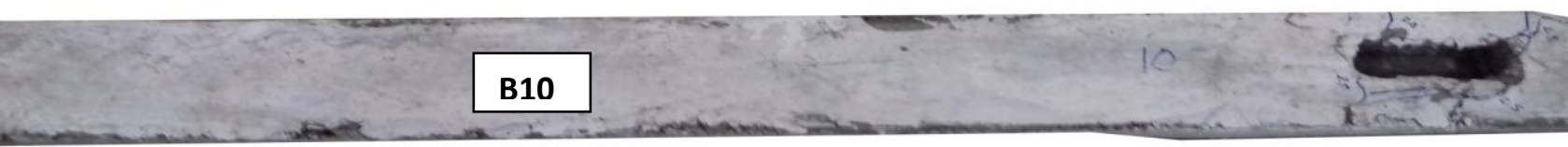

Figure 47: Cracking pattern of Beam B10

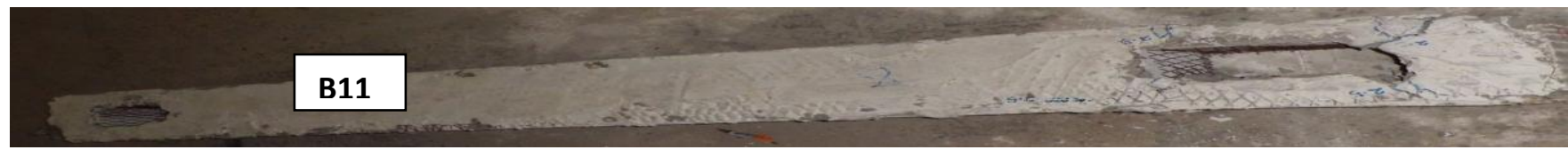

Figure 48: Cracking pattern of Beam B11

Figure 49: Cracking pattern of Beam B12

\section{Conclusions}


The test results of the current experimental program showed that the developed ferrocement beams with openings and reinforced with innovative reinforcing materials such as welded steel mesh and expanded steel mesh achieved high strength, better deformation characteristics, crack resistance, high ductility and energy absorption properties. Irrespective of the type and number of steel mesh layers and number of openings had better mechanical properties than conventional reinforced concrete beams. The results also demonstrated that Ferrocement concrete beams with openings showed fine crack widths at failure without spalling of concrete cover that is predominant.

Within the scope, parameters, theoretical and analytical investigation considered in this research and based on the test results and observations of the experimental investigation; the following conclusions and recommendations could be drawn as follows:

1. Saving in the total reinforcing steel weight ranging could be achieved by utilizing welded galvanized steel mesh, expanded metal mesh and polypropylene fibers for durability reason. The saving in the steel weight ranged from $20 \%$ to $30 \%$.

2. The beams incorporating ferrocement forms and high strength mortar matrix achieved higher first crack load, serviceability load, ultimate load, and energy absorption compared to that of control test specimen irrespective of the type of steel mesh and number of steel mesh layers.

3. Beam B10 with one opening at one end of the beam and strengthened with one layer of expanded steel mesh, volume fraction of reinforcing materials, $3.03 \%$ showed the high ductility ratio, 2.9 of all the strengthen beams.

4. Beam B1 without openings strengthen reinforced with two layers of welded steel mesh, volume fraction of reinforcing materials, $2.769 \%$ showed the energy absorption, $1803.85 \mathrm{KN} . \mathrm{mm}$ of all the tested strengthen beams.

5. Increasing the number of the steel mesh layers in the ferrocement forms increases the first crack load, serviceability load, ultimate load, and energy absorption. On the other hand it decreases the ductility of the beam which are very useful for dynamic applications.

6. Employing steel mesh in reinforcing concrete beams with openings, irrespective of the type of steel mesh and numbers of openings is significant in strengthening the matrix surrounding the openings and consequently improving strength, deformation characteristics and cracking behavior with great saving of reinforcement.

7. All tested beams with openings strengthen with various types of steel meshes showed at failure cracking control without spalling of concrete cover that is predominant due to the result of reducing stress concentration around the openings. 
8. The percentages of strength gain of all beams tested until failure were varied from $63.3 \%$ to $236 \%$ with controlling of all deformation characteristics with high ductility and energy absorption properties without spalling of concrete cover this is predominant,

9. The theoretical methods for first crack and ultimate load calculations provide good prediction for these loads and the beam's mode of failure.

10. The developed beams utilizing beams with openings reinforced with innovative reinforcing materials could be successfully used as an alternative to the traditional reinforced concrete beams, which can be of true merit in both developed and developing countries besides its anticipated economic and durability merits. Further research needs to be conducted to reach sound recommendations for practical use especially for the beams provided with four and five openings.

\section{Recommendations}

1. To study the viability of employing other types of mesh reinforcement in the ferrocement forms such as polypropylene mesh and tenax mesh.

2. To study the effect of employing internal ferrocement webs located in the transverse direction as shear reinforcement.

3. To develop light weight concrete beams with openings.

4. To examine further ways of producing lighter beams by reducing the weight of the core material by introducing longitudinal cavities in the core material.

5. To study the long term effects of the proposed beam system.

6. To investigate the dynamic loading effects on the proposed system.

\section{REFERENCES}

1. ACl Committee 549.1R.88, "Guide for the Design, Construction, and Repair of Ferrocement," book of $\mathrm{ACl}$ standards, vol. 04. 02, Philadelphia, 1989, pp. 1-23.

2. Fahmy, E., and Shaheen, Y. 1994. Laminated Ferrocement for Strengthening and Repairing of Reinforced Concrete Beams. Proceeedings of the Annual Conference of CSCE. 475-483

3. Fahmy, E.H., Shaheen, Y.B.I., and Korany. Y.S.. 1999. Repairing Reinforced Concrete Columns Using Ferrocement Laminates, Journal of ferrocement, 29, No.2, 115-124.

4. Fahmy, Ezzat H., Shaheen, Yousry B., and Abou Zeid, Mohamed N. 2004. Development of Ferrocement Panels for Floor and Wall Construction. Proceedings of the $5^{\text {th }}$ Structural Specialty Conference of the Canadian Society for Civil Engineering, Saskatoon, Saskatchewan, Canada ST218-1-ST218-10. 
5. $\mathrm{ACl}$ Committee 549. 1988. Guide for the design, construction, and repair of ferrocement, $\mathrm{ACl}$ Structural Journal (May-June): 325-351.

6. Irons, E., 1987. Laminated ferrocement for better repairs. Journal of Concrete International (September): 3441.

7. Anwar, M.W.; Nimityongskul, P.; Pama, R.P., and Robles-Austriaco, I., 1991. Method of rehabilitation of structural beam elements using ferrocement. Journal of Ferrocement 21(3): 229-234.

8. Fahmy, E.; Shaheen, Y.; and El-Dessouky, W. 1994. Laminated ferrocement for strengthening and repairing of reinforced concrete tanks. In the Proceeding of the Fifth International Colloquium on Concrete in Developing Countries, Cairo, Egypt.

9. Paramasivanm, P., Ong, K., and Lim, C. 1993. Repair of damaged R.C. beams using ferrocement laminates. In Proceeedings of the Fourth International Conference on Structural Failure, 613-620.

10. E.H.Fahmy, Y.B.Shaheen, and Y.S.Korany, "Repairing Reinforced Concrete Beams by Ferrocement", Journal of Ferrocement: Vol. 27, No. 1, January 1997. 